\title{
Treating COVID-19: Review of Drug Hypersensitivity Reactions
}

\author{
Dordal Culla $\mathrm{MT}^{1 *}$, Herrera-Lasso Regás V ${ }^{1 *}$, Martí-Garrido J1, Rodríguez Cumplido D², \\ Vázquez-Revuelta $\mathrm{P}^{1}$, Lleonart Bellfill $\mathrm{R}^{1}$
}

'Unitat d'Al-lergologia, Servei de Medicina Interna, Hospital Universitari de Bellvitge, Barcelona, Spain

${ }^{2}$ Servei de Farmacologia Clínica, Hospital Universitari de Bellvitge, Barcelona, Spain

*These authors contributed equally.

J Investig Allergol Clin Immunol 2020; Vol. 30(6): 385-399

doi: 10.18176/jiaci.0588

\begin{abstract}
The disease caused by the new severe acute respiratory syndrome coronavirus 2 (SARS-CoV-2), ie, coronavirus disease 2019 (COVID-19), has become a global pandemic since it was first reported in Wuhan, China in December 2019. Its severe clinical manifestations, which often necessitate admission to intensive care units, and high mortality rate represent a therapeutic challenge for the medical community. To date, no drugs have been approved for its treatment, and various therapeutic options are being assayed to address the pathophysiological processes underlying the clinical manifestations experienced by patients. New and old drugs administered as monotherapy or in combination to immunologically compromised patients may favor the development of adverse drug reactions, including drug hypersensitivity reactions, which must be identified and managed accordingly. Given the lack of herd immunity and the high rate of viral contagion, new cases are expected to emerge in the coming months. Thus, the probability of more adverse reactions or even new clinical manifestations may increase in parallel. Allergists must receive updated information on these treatments, as well as on the management of possible drug hypersensitivity reactions.
\end{abstract}

Key words: COVID-19. COVID-19 drug treatment. SARS-CoV-2. Adverse drug reaction. Drug hypersensitivity. Drug allergy.

\section{Resumen}

La enfermedad causada por el nuevo Severe Acute Respiratory Syndrome Coronavirus-2(SARS-CoV-2), Coronavirus Disease 2019(COVID-19), se ha expandido en forma de pandemia global desde su inicio en Wuhan (China) en diciembre de 2019. La aparición de formas clínicas graves asociadas a la necesidad de ingreso en unidades de Cuidados Intensivos, con un alto índice de letalidad, ha supuesto un reto terapéutico para la comunidad médica. Actualmente no hay ningún fármaco aprobado para su tratamiento y se están ensayando diversas opciones terapéuticas para abordar los procesos fisiopatológicos responsables de las manifestaciones clínicas que experimentan los pacientes. Tanto el uso de viejos como de nuevos principios activos como tratamiento único o en combinación, en pacientes inmunológicamente comprometidos, puede favorecer la aparición de efectos adversos, entre ellos reacciones de hipersensibilidad de mecanismo inmunológico, que habrá que saber identificar y manejar correctamente. Es de prever que, en los próximos meses, dada la falta de inmunidad comunitaria y el elevado índice de contagiosidad del virus, sigan surgiendo nuevos casos y, con ello, la probabilidad de que aparezcan más reacciones adversas o incluso nuevas manifestaciones clínicas. Es importante que los alergólogos estén al día de las opciones terapéuticas que se están utilizando, así como de sus posibles reacciones adversas, inclusive reacciones de hipersensibilidad y cómo manejarlas.

Palabras clave: COVID-19. Tratamiento COVID-19. SARS-CoV-2. Reacciones adversas. Hipersensibilidad fármacos. Alergia a fármacos. 


\section{Introduction}

The novel coronavirus disease 2019 (COVID-19) caused by severe acute respiratory syndrome coronavirus 2 (SARSCoV-2) was first reported in Wuhan, China in December 2019 and has become a pandemic in only a few months [1]. Community transmission rates are high, and the spectrum of disease ranges from severe respiratory illness and death from its complications (particularly in the elderly and in people with comorbidities) to an asymptomatic course $[1,2]$.

Once the disease manifests, supportive measures are initiated, although a systematic disease-modifying therapeutic approach remains empirical. Currently, there is no evidence from randomized controlled trials (RCTs) that any potential therapy could be superior to another, and many drugs are for compassionate or off-label use depending on experience, availability, and data from published case reports or short communications [3]. Pharmacotherapy targeting the virus seems to be useful when applied early in the course of the disease, although its usefulness in advanced stages may be doubtful $[4,5]$. Conversely, anti-inflammatory and immunosuppressive therapy applied too early can be dangerous [6], although it may prove useful in advanced stages owing to the damage caused by an amplified immune response and cytokine release (cytokine storm) [7]. Therefore, Siddiqi and Mehra [8] proposed a 3-stage classification system based on distinct clinical findings, response to therapy, and clinical outcome (Figure 1).

While a considerable effort has been made to flatten the curve of new contagions, the global pandemic is expected to continue. As more people are exposed to various treatments, we might expect to see a rise in the number of drug-related adverse effects, some of which have an immunological basis.

In this narrative review, we summarize current knowledge on the main immunological adverse drug reactions (ADRs) related to the drugs used to treat COVID-19 in order to identify them early and comprehensively address their management.

Our review is based on a search of the PubMed and Medline databases, search engines (including bibliographic references from 1966 to the present), SIETES (www.sietes.org, an information system on developments in clinical and therapeutic pharmacology), the clinical resource UptoDate (https://www. uptodate.com), and the Medinteract Drug Interactions Database (https://www.medinteract.net/).

\section{Antiviral Drugs}

\section{Lopinavir/Ritonavir}

Lopinavir/ritonavir is an approved combination oral antiretroviral treatment of the family of HIV protease inhibitors that acts on the CYP3A isoform of cytochrome P450.

Mechanism of action: Lopinavir has antiviral activity. Inhibition of HIV protease prevents cleavage of the gag-pol polyprotein, leading to the production of an immature, noninfectious virus. Lopinavir is active in vitro against SARS-CoV, the virus that causes SARS in humans [9]. Ritonavir is a pharmacokinetic enhancer used to increase the plasma half-life of lopinavir.

Rationale: Since clinical studies in SARS have reported reduced mortality and intubation rates for lopinavir in combination with other antiviral agents, it has been considered for COVID-19 [9,10].

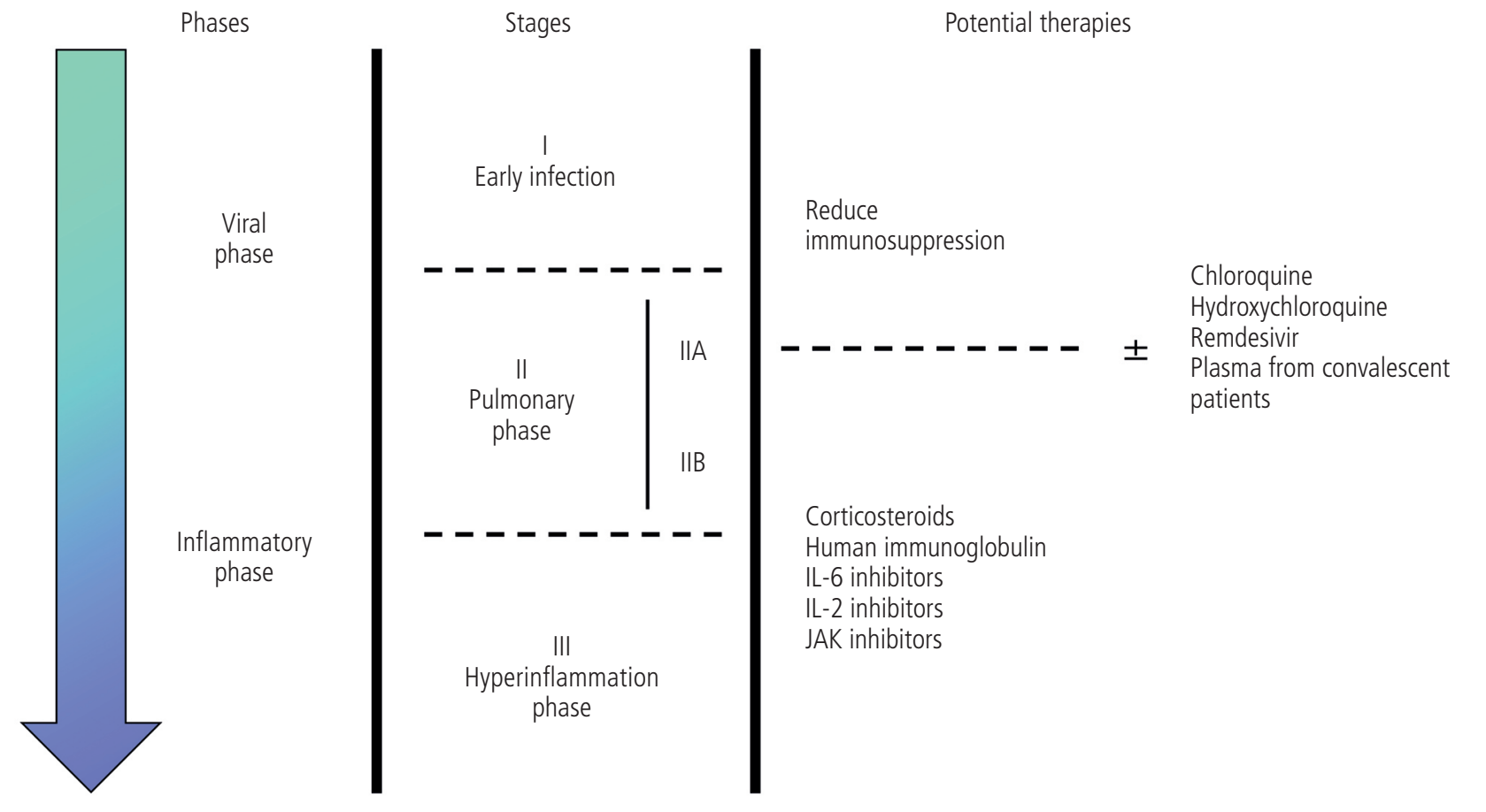

Figure 1. Proposed phases of COVID-19 disease progression and potential therapeutic targets. Adapted from Siddiqi et al [8]. IL indicates interleukin; JAK, Janus kinase. 
Table 1. Excipients Present in Commercial Preparations and Possible Inducers of Hypersensitivity Reactions (Adapted from Kang et al [11])

\begin{tabular}{ll}
\hline Excipient & Drug (Route of Administration) \\
\hline $\begin{array}{l}\text { Cremophor EL } \\
\text { (Polyoxyl 35 } \\
\text { hydrogenated castor oil) }\end{array}$ & Cyclosporine (intravenous) \\
$\begin{array}{l}\text { Cremophor RH 40 } \\
\text { (Polyoxyl 40 } \\
\text { hydrogenated castor oil) }\end{array}$ & $\begin{array}{l}\text { Cyclosporine (oral, capsule, } \\
\text { and solution) }\end{array}$ \\
$\begin{array}{l}\text { Cremophor RH } 60 \\
\text { (Polyoxyl 60 }\end{array}$ & $\begin{array}{l}\text { Tacrolimus (intravenous) } \\
\text { hydrogenated castor oil) }\end{array}$ \\
$\begin{array}{l}\text { Cremophor RH 40 } \\
\text { (Polyoxyl } 40\end{array}$ & $\begin{array}{l}\text { Lopinavir/ritonavir (oral, solution) } \\
\text { hydrogenated castor oil) }\end{array}$ \\
$\begin{array}{l}\text { Polysorbate } 80 \\
\end{array}$ & $\begin{array}{l}\text { Cyclosporine (oral, capsule) } \\
\text { Lopinavir/ritonavir (oral, tablet) } \\
\text { Tocilizumab (intravenous) } \\
\text { Anakinra (subcutaneous) }\end{array}$ \\
\hline
\end{tabular}

Drug hypersensitivity reactions (DHRs): Given the significant drug-drug interactions and potential ADRs, a careful review of concomitant medications and both clinical and analytical monitoring are required when this drug is used. Hypersensitivity and nonspecific mediator release have been reported for the excipients of the commercial formula (Table 1) [11] and for the drug itself. It should be noted that most cases are reported in HIV-infected patients, who are more prone than the general population to drug-related rash, and that published cases of hypersensitivity reactions by protease inhibitors are anecdotal, with reactions to other antiretrovirals, such as reverse transcriptase inhibitors (abacavir, nevirapine, efavirenz) being much more frequent [12]. Mild skin reactions such as maculopapular rash have been reported 7-10 days after ingestion [13], and a DHR has been demonstrated in vitro using the Cellular Antigen Stimulation Test in a case of pruritic rash [12]. More severe skin reactions have also been described: a case of acute generalized exanthematous pustulosis (AGEP) 24 hours after the first dose in a patient who received prophylaxis after occupational exposure [14], and a case of Stevens-Johnson-like syndrome associated with myeloid, hepatic, and renal toxicity after the first dose [15].

Allergological study: No in vivo tests have been reported.

Desensitization protocols: No desensitization protocols have been found.

\section{Remdesivir}

Mechanism of action: Remdesivir is a nucleotide analog that mimics adenosine, one of the building blocks of the RNA in the viral genome, and therefore interferes with viral RNA polymerization.

Rationale: This drug was initially developed for the Ebola virus outbreak, but it is a promising potential therapy for COVID-19 owing to its broad spectrum and potent in vitro activity against several novel coronaviruses, including SARS-CoV-2 [16]. While remdesivir is not currently approved, various clinical trials are ongoing to evaluate its safety and antiviral activity in patients with moderate-to-severe COVID-19 (including 5 clinical trials in Spain).

DHRs: One case of maculopapular rash with elevated aminotransferases was recently reported [17].

Desensitization protocols: No desensitization protocols have been reported.

\section{Azithromycin}

Azithromycin is an azalide. Azalides are a subclass of macrolide antibiotics.

Mechanism of action: Azithromycin works by inhibiting the synthesis of RNA-dependent bacterial proteins, binding to the 50s subunit of the ribosome, and inhibiting translocation of the peptides.

Rationale: Azithromycin is thought to have antiviral and anti-inflammatory activity and may work synergistically with other antiviral treatments. In recent years, the antiviral effects of macrolides have attracted considerable attention against rhinovirus, influenza, and the Zika and Ebola viruses [18].

DHRs: Macrolides are generally well tolerated, and allergy to them is infrequent $(0.4 \%$ to $3 \%)$ [19]. However, some cases of immediate hypersensitivity (including urticaria, angioedema, and anaphylaxis) and delayed hypersensitivity (fixed drug eruptions [FDE] and severe cutaneous adverse reactions [SCARs]) have been described with macrolides [20-22]. SCARs with azithromycin include drug reaction with eosinophilia and systemic symptoms (DRESS) syndrome [23], AGEP [24], Stevens-Johnson syndrome (SJS) [25,26], and vasculitis [27].

Organ-specific reactions with hepatic involvement have also been described [28]. The long half-life of azithromycin could explain why hypersensitivity reactions are especially delayed.

Allergological study: Diagnostic procedures include a detailed clinical history, skin tests, and provocation tests. Despite being highly irritative drugs for skin testing, experience with azithromycin has been reported. The Spanish Society of Allergology and Clinical Immunology proposes to carry out prick testing at $10 \mathrm{mg} / \mathrm{mL}$ and intradermal testing at $0.01 \mathrm{mg} / \mathrm{mL}$ [29]. Patch testing (20\% pet) [29] can be an option for delayed reactions, although its sensitivity is low. If skin tests are negative, the risk-benefit ratio should be evaluated before proceeding with a drug provocation test (DPT). Crossreactivity between different macrolides seems to be infrequent, although it is necessary to confirm tolerance to another drug in cases of confirmed allergy to azithromycin [30].

Desensitization protocols: There are very few published reports of macrolide desensitization. One involved a patient diagnosed with mast cell activation syndrome who was successfully desensitized to azithromycin following a 14-step protocol, achieving a total dose of $528.45 \mathrm{mg}$ in 24 hours [31].

\section{Chloroquine/Hydroxychloroquine}

Hydroxychloroquine is a 4-aminoquinoline similar to chloroquine with antimalarial and immunomodulatory effects. 
Mechanism of action: Regarding its immunomodulatory effects, chloroquine/hydroxychloroquine (CQ/HCQ) can attenuate cytokine production and inhibit autophagy and lysosomal activity in host cells [32]. In vitro, CQ/HCQ possesses antiviral activity against RNA and DNA viruses [33].

Rationale: $\mathrm{CQ} / \mathrm{HCQ}$ acts at 2 key steps that are required for cell entry by coronaviruses: inhibition of receptor binding (interfering with the glycosylation of angiotensin-converting enzyme 2, the cellular receptor of SARS-CoV-2) and inhibition of membrane fusion (CQ/HCQ concentrate in lysosomes, increasing their $\mathrm{pH}$ and preventing viral protease activity) [32].

DHRs: $\mathrm{CQ} / \mathrm{HCQ}$ are relatively well tolerated, although both can cause serious adverse effects such as prolongation of the QTc interval, gastrointestinal symptoms, and hypoglycemia. As for immunological reactions, both mild skin eruptions (maculopapular rash, urticaria) and SCARs (toxic epidermal necrolysis [TEN] SJS, AGEP, DRESS syndrome), including erythema multiforme, have been reported [34-39]. CQ/HCQ has also been associated with photosensitivity [33].

Allergological study: Patch tests with CQ/HCQ (30\% pet) have been reported in delayed reactions, with both negative and positive results $[34,36,37,39]$. In cases of immediate reactions, Soria et al [34] found that prick tests with the undiluted drug yielded negative results. In cases of anaphylaxis, dilution up to $1 / 10000$ has been advised [40]. If skin tests are negative, the risk-benefit ratio should be evaluated before proceeding with a DPT.

Desensitization protocols: Several slow desensitization protocols have been published [41], with increasing doses at 24-hour intervals and lasting from 4 days [42] to 36 days [43] to achieve the full dose. A case of rapid desensitization to HCQ (less than 24 hours) was recently published [44].

\section{Anticytokine or Immunomodulatory Agents}

\section{Tocilizumab}

Tocilizumab is a humanized monoclonal antibody interleukin (IL) 6 receptor antagonist.

Mechanism of action: IL-6 is a proinflammatory cytokine involved in various physiological processes, such as activation of T lymphocytes, induction of immunoglobulins and acutephase proteins, and stimulation of hemopoiesis. IL- 6 has been implicated in the pathogenesis of inflammatory diseases, osteoporosis, and malignancies

Rationale: Studies conducted in patients who died of SARS and Middle East respiratory syndrome (MERS) suggest that mortality is associated with an amplified immune response with cytokine release [45]. Although tocilizumab has shown promising results in some studies [46], the lack of a comparator group warrants caution when interpreting the results. Several RCTs with tocilizumab are ongoing in patients with severe COVID-19.

DHRs: Immediate DHRs (urticaria, anaphylaxis) and delayed DHRs (including urticaria, maculopapular rash, vasculitis, AGEP, SJS, and DRESS syndrome) can occur after taking tocilizumab [47-51]. Non-IgE-mediated alpha reactions related to cytokine release have also been reported [49]. It is important to take hypersensitivity to excipients into account (Table 1) [11].

Allergological study: Skin testing with tocilizumab is usually performed at $20 \mathrm{mg} / \mathrm{mL}$ for the prick test and $0.2 \mathrm{mg} / \mathrm{mL}$ [29], $20 \mathrm{mg} / \mathrm{mL}[52]$, or $2 \mathrm{mg} / \mathrm{mL}[49,53]$ for the intradermal test. If the results of skin tests are negative, a DPT can be performed after evaluating the risk-benefit ratio. Switching to the subcutaneous route can be considered [49].

Desensitization protocols: Desensitization to tocilizumab has been reported, both in immediate and in delayed reactions [53-55]. Demir et al [56] described 65 rapid drug desensitizations with tocilizumab in 3 patients, with only 1 episode of anaphylaxis during the fifth desensitization cycle. However, after modifying the protocol, this patient was able to continue the protocol uneventfully.

\section{Sarilumab}

Sarilumab is a human monoclonal antibody against the IL-6 receptor.

Mechanism of action: The same as that of tocilizumab.

Rationale: Several phase 2-3 clinical trials have evaluated the efficacy of sarilumab in patients with severe COVID-19 [3].

DHRs: One published article reported mild-to-moderate rashes in 4 patients treated with sarilumab, although the reaction did not require treatment to be stopped [57]. Injection site reactions have also been reported [58].

Desensitization protocols: To date, no desensitization protocols have been reported.

\section{Anakinra}

Anakinra is a recombinant nonglycosylated form of the human IL-1 receptor antagonist (IL-1R $\alpha$ ).

Mechanism of action: The IL-1 family is a group of proinflammatory cytokines, with IL $-1 \alpha$ and IL- $1 \beta$ having the greatest inflammatory effect. Through the expression of integrins in leukocytes and endothelial cells, they regulate and initiate the inflammatory response [59]. Anakinra neutralizes the biological activity of IL- $1 \alpha$ and IL- $1 \beta$ by competitively inhibiting their binding to the type I receptor [59].

Rationale: In a recent study, continuous intravenous infusion of anakinra resulted in rapid serologic and subsequent clinical improvement in adult patients with macrophage activation syndrome [60], suggesting that this agent could be an option for treatment of patients with severe COVID-19 who experience a cytokine storm.

DHRs: Local reactions consisting of inflammation, erythema, itching, and pain are frequent with anakinra owing to the large amount of protein in the solution, which produces mast cell degranulation [61]. It is possible to prevent both immediate local reactions (application of ice locally before and after the injection and ensuring that the liquid is at room temperature prior to administration) and late local reactions (alternative injection sites and application of local topical corticosteroids). Case reports show that systemic allergic reactions to anakinra range from mild-to-moderate rash to anaphylaxis [62-65]. Anakinra contains polysorbate 80 as an excipient; this may also cause DHR [66-68].

Allergological study: One article reported a positive skin prick test with undiluted drug [63], and another described a 
positive intradermal test result at the $1 / 10$ concentration [64]. If skin tests are negative, the risk-benefit ratio should be evaluated before proceeding with a DPT.

Desensitization protocols: The few published case reports of successful rapid subcutaneous desensitizations advise starting with a dilution of $1 / 1000$ [65] and increasing to $1 / 100$ [64].

\section{Baricitinib}

Baricitinib is a selective and reversible inhibitor of Janus kinase (JAK) types 1 and 2.

Mechanism of action: Baricitinib reversibly inhibits JAK1/ JAK2, and, through a transduction pathway signal involving STAT proteins, it ultimately modulates the expression of genes associated with inflammation in immune cells by means of an anti-inflammatory effect.

Rationale: Inhibition of JAK1/JAK2 could therefore have a potential role in reducing systemic inflammation and lung damage. This drug may also reduce receptor-mediated SARS-CoV-2 endocytosis by inhibiting the adaptor protein-2 complex-associated protein kinase 1 [69]. Clinical trials are underway to assess its effectiveness.

DHRs: There is a reported case of palmoplantar pustulosislike eruption due to baricitinib [70].

Desensitization protocols: To date, no desensitization protocols have been described.

\section{Cyclosporine}

Cyclosporine is an immunosuppressant peptide isolated from the fungus Tolypocladium inflatum.

Mechanism of action: Cyclosporine binds to the cyclophilin protein of $\mathrm{T}$ lymphocytes to form a complex that, in turn, inhibits the activity of calcineurin, thus preventing the transcription of multiple genes associated with inflammatory cytokines. It also acts on the mitochondria by inhibiting their apoptosis.

Rationale: Cyclosporine has been shown to inhibit the replication of several coronaviruses in vitro at noncytotoxic concentrations and independently of its immunosuppressive effect $[71,72]$. It also reduces cell proliferation and the concomitant production of cytokines.

DHRs: Cases of hypersensitivity/nonspecific release of mediators associated with excipients in the formula have been reported (Table 1) [11]. Polyoxyethylated castor oil (Cremophor EL) is a nonionic surfactant that is extracted from the seeds of Ricinus communis and used as a vehicle in hydrophobic medications such as cyclosporine. It can cause itching, erythematous rash, urticaria, angioedema, facial flushing, bronchospasm, dyspnea, nausea, vomiting, and anaphylaxis following infusion. The probable pathophysiological mechanisms underlying this reaction include IgE-mediated immune response, complement activity, histamine release by basophils or mast cells, and IgG antibody formation [73]. Assuming that Cremophor EL is the culprit agent in hypersensitivity to intravenous cyclosporine, corn oilbased soft gelatin capsules, which contain polyoxyethylated glycolyzed glycerides, would be a safe alternative in cases of hypersensitivity to other forms of cyclosporine [74].
This observation has been confirmed elsewhere [11,75-77]. Finally, the basophil activation test (BAT) can be used as a diagnostic tool for both cyclosporine- and excipient-induced hypersensitivity $[73,75]$.

Allergological study: Cyclosporine and Cremophor EL have been tested at $1 / 1000$ to $1 / 1$ for prick testing and at $1 / 1000$ and $1 / 100$ for intradermal testing $[73,74]$. If the results of skin tests are negative, the risk-benefit ratio should be evaluated before proceeding with a DPT.

Desensitization protocols: One successful slow oral cyclosporine desensitization protocol has been reported (11 days) [78].

\section{Tacrolimus}

Tacrolimus is a macrolide immunosuppressant produced by the bacteria Streptomyces tsukubaensis.

Mechanism of action: Tacrolimus inhibits signal transduction pathways in $\mathrm{T}$ lymphocytes and prevents transcription of multiple proinflammatory cytokine-related genes (IL-2), as well as type 1 interferons [79].

Rationale: Clinical trials are currently underway in severe SARS-Cov-2 pneumonia based on the ability of tacrolimus to counteract excessive inflammation caused by the associated cytokine storm [7].

DHRs: Cases of hypersensitivity/nonspecific release of mediators caused both by excipients of the drug (Table 1) and by the drug itself have been reported [11]. The intravenous form of tacrolimus contains polyoxyethylated castor oil, which can induce various ADRs, including anaphylaxis (see Cyclosporine). If the excipient is the culprit agent of the ADR, patients may tolerate oral tacrolimus, which lacks this excipient [80]. Allergic contact dermatitis to tacrolimus has been demonstrated with positive patch test results at $2.5 \%$ in alcohol [81]. Recently, a case of contact urticaria by a tacrolimus-containing ointment [82] and a case of symmetrical drug-related intertriginous and flexural exanthema (SDRIFE) with oral tacrolimus [83] were published.

While tacrolimus is a macrolide drug, its chemical structure differs substantially from that of macrolide antibiotics. A case report describing cross-sensitivity between tacrolimus and macrolides was found, although the patient had been diagnosed with allergy to clarithromycin without an allergy work-up [84]. On the other hand, in a retrospective review of 8 patients with reported macrolide allergy (not confirmed), all of them tolerated tacrolimus (including 3 patients with an anaphylactic-type reaction) [85]. Exposure to tacrolimus was recently associated with posttransplantation food allergy in a large cohort from a pediatric tertiary care center [86].

Desensitization protocols: No desensitization protocols have been found.

\section{Miscellaneous}

\section{Ivermectin}

Ivermectin is an antiparasitic agent isolated from the fermented broth of the bacteria Streptomyces avermitilis.

Mechanism of action: Ivermectin binds to the chlorine channels of nerve and muscle cells in invertebrate 
microorganisms, causing paralysis and death of the parasite. Ivermectin has also been proven to be active against various viruses in vitro.

Rationale: Ivermectin was recently reported to be a potent inhibitor of SARS-Cov-2 replication in vitro [87]. However, available evidence suggests that levels of ivermectin with meaningful activity against SARS-CoV-2 would not be achieved without potentially toxic increases in ivermectin dosing levels in humans [88]. Therefore, well conducted clinical trials are required.

DHR: The main adverse events are pruritus and rash, which usually appear during the first days of treatment [89-91]. A few case reports of ivermectin-associated SCARS (TEN, SJS, and DRESS syndrome) have been published [92-94]. There is 1 published case of FDE following ivermectin [95]. No allergological studies were performed in these cases.

Desensitization protocols: To date, no desensitization protocols have been published.

\section{Icatibant}

Icatibant is a synthetic decapeptide with a structure similar to that of bradykinin. It has been approved for use in the treatment of acute angioedema attacks in patients with hereditary C1-inhibitor deficiency.

Mechanism of action: Bradykinin is a direct end product of the kallikrein-kinin system. It binds to the bradykinin type 2 receptors (BK2) on the vascular endothelium. Icatibant acts as a specific antagonist of BK2 receptors.
Rationale: The SARS-CoV-2 virus enters respiratory epithelial cells through the ECA2 receptor [96]. ECA2 is responsible for the catabolism of des-Arg9-bradykinin, and a decrease in its activity implies an increase in bradykinin levels $[97,98]$. The pulmonary edema present in the early stages of pneumonia in COVID-19 could therefore be caused by local activation of the bradykinin receptors located in the endothelial cells [99], which would result in vasodilation and increased vascular permeability leading to pulmonary edema and inflammation.

Finally, a theoretical computational model showed icatibant to be a possible inhibitor of SARS-CoV-2 protease M, a key enzyme in the replication of coronavirus [100]. The proposed timing of treatment with icatibant in COVID-19 is depicted in Figure 2.

DHRs: The most common adverse effects are injection site reactions, which are generally mild in severity and transient in nature [101-104].

Desensitization protocols: No desensitization protocols have been published.

\section{Corticosteroids}

Corticosteroids are a class of steroid hormones produced in the adrenal cortex. They have anti-inflammatory, immunosuppressive, and antiproliferative effects.

Rationale: Corticosteroids decrease the host inflammatory response in the lungs, which, if not stopped, may lead to acute lung injury and SARS. However, this benefit may be eclipsed

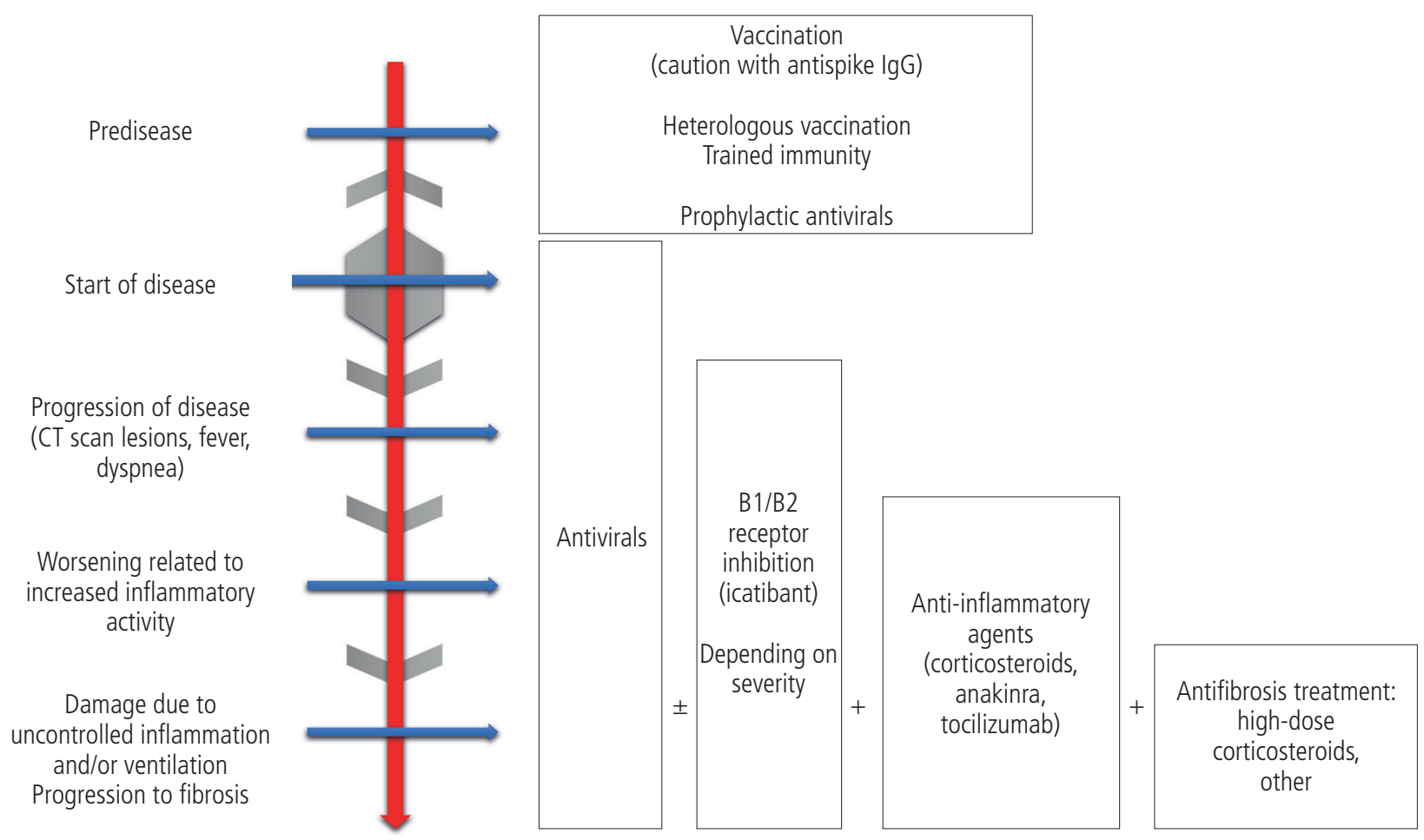

Figure 2. Proposed targeted treatments for COVID-19 and timing of administration. Adapted from Van der Veerdonk F et al. [99]. B1/B2 indicates bradykinin receptor $1 / 2 ; \mathrm{CT}$, computed tomography; IgG, immunoglobulin $\mathrm{G}$. 
by possible adverse effects, including delayed viral clearance and increased risk of secondary infection. Observational studies and systematic reviews report inconclusive clinical evidence on the effects of corticosteroid therapy for viral pneumonia such as that induced by SARS and MERS $[105,106]$. Nevertheless, the investigators of the Randomised Evaluation of COVid-19 thERapY (RECOVERY) Trial, which enrolled over 11500 patients infected with COVID-19 in the United Kingdom, recently stated that dexamethasone reduced deaths by one-third in ventilated patients and one-fifth in other patients receiving oxygen only [107]. These results are to be published shortly, given their importance for public health.

DHRs: According to their chronology, DHRs are classified as immediate, ie, appearing within a few minutes/hours of administration (incidence estimated between 0.1-0.3\%), and delayed, ie, appearing 24-48 hours after administration or even later (incidence estimated at $0.3 \%-6 \%$ ) [108].

Immediate DHRs usually occur following systemic therapy (except for intra-articular administration, where there could be a delayed reaction) and manifest clinically as pruritus, rash, urticaria, angioedema, rhinoconjunctivitis, bronchospasm, anaphylaxis, hypotension, vascular collapse, and death [108-110]. Immediate DHRs are more frequent with hydrocortisone, methylprednisolone, or a specific salt (succinate), although they may also be due to the excipients (carboxymethyl cellulose, benzyl alcohol, propylene glycol, polyethylene glycol, polysorbate 80 , or parabens) $[108,111]$. Reactions to systemic therapy are more frequent in asthmatics with hypersensitivity to aspirin, transplant recipients, patients with nephritis, hemodynamically unstable patients, and patients with rheumatic diseases [108,112].

Delayed DHRs are usually due to topical corticosteroids and mainly affect atopic patients and patients with contact dermatitis, ulcers, stasis dermatitis, and other previous dermatological disorders [113]. Worsening of such disorders, as well as bronchospasm and pain in the nasal or oral mucosa after nasal or bronchial application, may also appear. Furthermore, delayed DHRs can manifest after systemic therapy and range from rash, eczema, blistering, and purpura to SDRIFE, FDE, SJS, and AGEP [114].

Table 2 shows the main differences between immediate and delayed DHRs induced by corticosteroids.

Allergological study: The diagnostic procedure includes skin testing and DPTs. Patch testing has been proven to be useful for the study of delayed reactions mediated by a type IV hypersensitivity mechanism. In general, corticosteroids are tested at concentrations ranging from $0.1 \%$ to $1 \%$. In addition to the usual readings at $48-96$ hours,

Table 2. Differential Diagnosis of Immediate and Delayed Hypersensitivity Reactions to Corticosteroids (Adapted from Rosado-Ingelmo [108])

\begin{tabular}{lll} 
& Immediate Hypersensitivity & Delayed Hypersensitivity \\
\hline Frequency & Rare & Contact dermatitis: common \\
Main route of sensitization & Intravenous & Cutaneous \\
Latency period & Minutes after exposure & Hours or days after exposure
\end{tabular}

Clinical presentation

Drugs most

frequently implicated

In vivo diagnostic tests

Cross-reactivity patterns

Alternatives
Urticaria, angioedema, pruritus, rhinoconjunctivitis, bronchospasm, and anaphylaxis

Hydrocortisone (ester succinate) Methylprednisolone

Prick test Intradermal test

Drug provocation test

Uncertain

Hydrocortisone -

Methylprednisolone (?)

Individualized assessment of sensitization/tolerance profile. Betamethasone, dexamethasone, and deflazacort are usually well tolerated
Worsening of previous skin condition, rash, eczema, and contact dermatitis

Occasionally after systemic administration: rash, purpura, SDRIFE, FDE, SJS, and AGEP

Budesonide

Hydrocortisone

Methylprednisolone

Dermatitis is more frequent with corticosteroids from groups $\mathrm{A}, \mathrm{B}$, and $\mathrm{D} 2$ of the Coopman classification Topical nonfluorinated corticosteroids induce more allergic contact reactions than fluorinated corticosteroids

Patch test

Intradermal test (delayed reading)

Repeat open application test

Drug provocation test

According to the Baeck classification:

- Profile 1: allergy only to group 1

- Profile 2: potential allergy to all/various corticosteroids

- Profile 1: groups 2 and 3

- Profile 2: individualized assessment of the sensitization/tolerance profile

Abbreviations: AGEP, acute generalized exanthematous pustulosis; FDE, fixed drug eruption; SDRIFE, symmetrical drug-related intertriginous and flexural exanthema; SJS, Stevens-Johnson syndrome. 
it is important to take a reading on the seventh day, as the anti-inflammatory effect of the drug itself may delay a positive response [115]. A repeated open application test can be an option if patch test results are negative [116]. This consists of twice-daily topical application on the anterior aspect of the forearm for 7 days. Commercial preparations are used for the prick test and intradermal test. Although assays for in vitro testing for hypersensitivity to corticosteroids are primarily research tools and are not commercially available, specific IgE and BATs have been noted to be positive in some cases $[117,118]$. It is also important to test the excipients, if possible [111]. If skin test results are negative, the risk-benefit ratio should be evaluated before proceeding with a DPT.

Regarding cross-reactivity, certain patterns have been described in delayed contact reactions, as follows:

- According to the Coopman classification [113], classes $\mathrm{C}$ and $\mathrm{D} 1$ produce fewer allergic reactions and have little cross-reactivity, whereas classes A, B2, and budesonide produce more allergic reactions and have greater intragroup and intergroup cross-reactivity.

- According to the Baeck classification [119], which distinguishes between non-C16-methyl molecules, most nonhalogenated corticosteroids (group 1) with a $\mathrm{C} 16 / \mathrm{C} 17$ cis ketal/diol structure, most halogenated corticosteroids (group 2) and agents with C16-methyl substitution, and most halogenated agents (group 3), we can distinguish 2 patient profiles: allergic only to group 1 (able to tolerate groups 2 and 3 ) and potentially allergic to any corticosteroid (a systematic and individualized evaluation would be necessary to find a therapeutic alternative).

In immediate reactions, these cross-reactivity patterns are not applicable. A systematic and individualized evaluation is necessary to find a therapeutic alternative [114]. Some studies have shown cross-reactivity between hydrocortisone, methylprednisolone, and prednisolone, which have C21 esterification in common, and recommend, as an alternative, halogenated agents such as betamethasone and dexamethasone [120].

Desensitization protocols: This topic is addressed in 2 case reports. One describes a case of desensitization to hydrocortisone prior to the administration of radiological contrast medium in a patient allergic to corticosteroids and iodinated contrasts [121]. The other describes a case of desensitization to methylprednisolone hemisuccinate in a patient who subsequently tolerated another methylprednisolone salt [122].

\section{Heparins}

Heparins are important anticoagulants used in the prophylaxis and treatment of thromboembolic disorders. They include unfractionated heparins and low-molecular-weight heparins (LMWHs) [123,124].

Mechanism of action: The anticoagulant effect of heparin is mediated through its interaction with antithrombin III, which, in turn, accelerates its ability to inactivate the coagulation factors IIa, Xa, and IXa.
Rationale: Severe COVID-19 is commonly complicated by coagulopathy and disseminated intravascular coagulation [125-127]. All patients hospitalized with COVID-19 should receive prophylactic heparin to prevent venous thromboembolism [128].

DHRs: Delayed DHR to subcutaneously injected heparin is the most commonly reported reaction [129-131], with LMWHs being the most frequently involved [132]. Itchy erythematous or eczematous plaques develop around the injection site. The usual latency for development of characteristic lesions during ongoing therapy is 7 to 10 days; in cases of prior sensitization and re-exposure, skin lesions appear within 1 to 3 days [133]. Less frequently, in cases with continuation of subcutaneous injections despite local reactions, generalized eczema or exanthema with accentuation around the injection site may be observed [134]. Female sex, older age, and longer exposure to heparins seem to be risk factors for heparin allergy [135].

Other immune reactions during ongoing anticoagulation with heparins may present as heparin-induced thrombocytopenia, a classic type II reaction induced by polyclonal antibodies [132], and type III Arthus reaction, resulting from antigen-antibody complexes and characterized by inflammation, erythematous induration, and edema at the injection site, which can result in subsequent hemorrhage and necrosis [136]. In rare cases, DRESS syndrome [137], SJS [138], and IgE-mediated urticaria and anaphylaxis have been described [124,139-144].

As little is known about cross-reactivity between heparins, tolerance must always be demonstrated [124]. Tolerance does not seem to depend on molecular weight [145]. Tolerance to fondaparinux is well known in patients who react to LMWHs [146], and data in the literature show that patients with delayed DHR to heparins tolerate intravenous heparin [132,147,148].

Allergological study: For immediate reactions, the sensitivity and specificity of skin tests have yet to be determined [149]; therefore, according to some authors $[149,150]$, the BAT could be a useful in vitro diagnostic technique when investigating possible sensitization to heparins. Prick tests using the original undiluted drug are not necessary in patients with delayed DHRs, and patch testing with the undiluted drug can be omitted because of reduced sensitivity [132]. Intradermal testing with drug concentrations ranging from $1 / 1000$ to $1 / 10$ are recommended $[151,29]$. If cutaneous tests are negative, the risk-benefit ratio should be evaluated before proceeding with a DPT.

Desensitization protocols: Many desensitization protocols have been reported [143,144,152-154]. One involved desensitization to heparin before cardiopulmonary bypass by gradually increasing the dose of intravenous heparin, starting with 100 units in $1 \mathrm{~L}$ of saline over 24 hours [144]. Another describes a successful 3-hour desensitization protocol after an anaphylactic shock due to heparin comprising intravenous administration of diluted heparin, with doses gradually increasing ( 0.1 to 5000 units) at 15 -minute intervals [143].

Table 3 provides a summary of DHRs. Table 4 provides detailed concentrations for the prick and patch tests mentioned in this review, as well as other possible options. 
Table 3. Summary of all Drug Hypersensitivity Reactions for the Drugs Included in This Review

\begin{tabular}{|c|c|c|c|}
\hline Drug & Immediate reactions & Nonimmediate Reactions & $\begin{array}{c}\text { Desensitization Protocols } \\
\text { [Reference] }\end{array}$ \\
\hline Lopinavir/Ritonavir & NR & MPE, AGEP, SJS & NR \\
\hline Remdesivir & NR & MPE & NR \\
\hline Azithromycin & $\begin{array}{l}\text { Urticaria, angioedema, } \\
\text { anaphylaxis }\end{array}$ & $\begin{array}{l}\text { MPE, FDE, AGEP, DRESS, SJS, } \\
\text { vasculitis, organ-specific reactions }\end{array}$ & {$[31]$} \\
\hline $\begin{array}{l}\text { Chloroquine / } \\
\text { Hydroxychloroquine }\end{array}$ & Urticaria & $\begin{array}{l}\text { MPE, AGEP, DRESS, EM, SJS, TEN, } \\
\text { photosensitivity }\end{array}$ & {$[41-44]$} \\
\hline Tocilizumab & Urticaria, anaphylaxis & $\begin{array}{l}\text { Urticaria, MPE, AGEP, SJS, DRESS, } \\
\text { vasculitis }\end{array}$ & {$[53-56]$} \\
\hline Sarilumab & NR & $\begin{array}{l}\text { Pruritic rash, } \\
\text { delayed local reactions }\end{array}$ & NR \\
\hline Anakinra & $\begin{array}{l}\text { Immediate local reactions, urticaria, } \\
\text { angioedema, anaphylaxis }\end{array}$ & Delayed local reactions & {$[64,65]$} \\
\hline Baricitinib & NR & Palmoplantar pustulosis & NR \\
\hline Cyclosporine & $\begin{array}{l}\text { Urticaria, angioedema, pruritic rash, } \\
\text { bronchospasm, anaphylaxis }\end{array}$ & & {$[78]$} \\
\hline Tacrolimus & $\begin{array}{l}\text { Urticaria, angioedema, pruritic rash, } \\
\text { bronchospasm, anaphylaxis }\end{array}$ & Allergic contact dermatitis, SDRIFE & NR \\
\hline Ivermectin & Urticaria, pruritic rash & MPE, TEN, SJS, DRESS, FDE & NR \\
\hline Icatibant & NR & Local reactions & NR \\
\hline Corticosteroids & $\begin{array}{l}\text { Urticaria, pruritic rash, angioedema, } \\
\text { rhinoconjunctivitis, bronchospasm, } \\
\text { anaphylaxis }\end{array}$ & $\begin{array}{l}\text { Rash, eczema, allergic contact dermatitis, } \\
\text { purpura, worsening of previous cutaneous } \\
\text { disorders, SDRIFE, FDE, SJS, AGEP }\end{array}$ & {$[121,122]$} \\
\hline Heparins & Urticaria, anaphylaxis & $\begin{array}{l}\text { Delayed local reactions, generalized eczema } \\
\text { or exanthema, DRESS, SJS, heparin-induced } \\
\text { thrombocytopenia }\end{array}$ & d $[143,144,152-154]$ \\
\hline
\end{tabular}

Abbreviations: AGEP, acute generalized exanthematous pustulosis; DRESS, drug reaction with eosinophilia and systemic symptoms; EM, erythema multiforme; FDE, fixed drug eruption; MPE, maculopapular eruption; NR, not reported to date; SDRIFE, symmetrical drug-related intertriginous and flexural exanthema; SJS, Stevens-Johnson syndrome; TEN, toxic epidermal necrolysis.

\section{Other Adverse Reactions}

Although our review has focused on DHRs, the therapies presented may be responsible for other ADRs, some of which could prove severe. The main serious adverse reactions reported are gastrointestinal effects, severe infections, prolongation of the QT interval and other electrocardiographic abnormalities, drug interactions, hematological and metabolic disorders, and nephrotoxicity.

\section{Limitations}

Our review is subject to a series of limitations. Firstly, the number of articles published in the last few weeks and the speed with which they are being published imply that the recommendations and even the drugs used to treat the disease are constantly being modified. Therefore, some may not appear in this review. Secondly, this is not a systematic review, but rather a narrative review. The DHRs described appear in the databases reviewed, although some may not have been reported or published. Finally, considering the types of reaction that are the subject of this review, only 2 suspicions of DHRs have been registered in the Pharmacovigilance Program of Hospital Universitari de Bellvitge, Barcelona, Spain since 2007: one with cyclosporine and the other with azithromycin [155].

\section{Final Thoughts About COVID-19 and Drug Hypersensitivity}

A new disease implies new therapeutic challenges; however, to date, no treatment has been definitively shown to improve the prognosis of patients with COVID-19. At present, most published work consists of small observational studies or case series, with no randomization or control groups. While some drugs have shown in vitro activity, their potential clinical benefits are unclear. Furthermore, the use of any medication relies on the assumption that the benefits outweigh the associated risks, and increased toxicity with combination therapy requires a careful evaluation of the risk-benefit ratio. 
Multiple RCTs are currently underway and are expected to provide further therapeutic evidence in the near future. Moreover, as the mechanisms of action of the virus become better known, new lines of treatment are expected to emerge. Figure 2 illustrates the targeted treatments proposed and the time schedule according to which they should be administered [99].
It is expected that new therapeutic options, new indications, and a greater number of possible COVID-19 patients taking these drugs will generate more ADRs. While new drugs seem to have little ability to generate an immune response, it remains to be seen what will happen in the future with increased use. As allergists, we must keep up to date on the possible spectrum of hypersensitivity reactions with these treatments in order

Table 4. Concentrations Used for Skin Tests

\begin{tabular}{|c|c|c|c|c|}
\hline Drug class & Drug & Prick Test & Intradermal Test & Patch Test \\
\hline \multirow[t]{9}{*}{ Antivirals } & Lopinavir/ritonavir & NR & NR & NR \\
\hline & Remdesivir & NR & NR & NR \\
\hline & Azithromycin & $10 \mathrm{mg} / \mathrm{mL}[29]$ & $0.01 \mathrm{mg} / \mathrm{mL}[29]$ & $20 \%$ pet $[29,157]$ \\
\hline & & & $0.1 \mathrm{mg} / \mathrm{mL}[156]$ & $1-5 \%$ pet $[158]$ \\
\hline & Chloroquine/ & $1 / 10000[41]$ & NR ?? & $30 \%$ pet $[35]$ \\
\hline & hydroxychloroquine & Undiluted [35] & & CQ: $1 \%-5 \%$ aq, \\
\hline & & $2-20 \mathrm{mg} / \mathrm{mL}[40]$ & & $1 \%-5 \%$ pet $[157]$ \\
\hline & & & & HCQ: $5 \%$ aq [157], \\
\hline & & & & $10 \%$ DMSO [39] \\
\hline \multirow{9}{*}{$\begin{array}{l}\text { Anticytokine/ } \\
\text { immunomodulatory } \\
\text { agents }\end{array}$} & Tocilizumab & $20 \mathrm{mg} / \mathrm{mL}[49,159]$ & $0.2 \mathrm{mg} / \mathrm{mL}[29,159]$ & \\
\hline & & & $2 \mathrm{mg} / \mathrm{mL}[49,53]$ & \\
\hline & & & $20 \mathrm{mg} / \mathrm{mL}[52]$ & NR \\
\hline & Sarilumab & NR & NR & NR \\
\hline & Anakinra & Undiluted [64] & $1 / 10[65]$ & $\mathrm{NR}$ \\
\hline & Baricitinib & NR & NR & NR \\
\hline & Cyclosporine & $1 / 1000$ to $1 / 1[73,74]$ & $1 / 1000$ to $1 / 100[73,74]$ & NR \\
\hline & Tacrolimus & & & $2.5 \%$ alc $[82]$ \\
\hline & & & & $2.5 \%$ pet $[157]$ \\
\hline \multirow[t]{14}{*}{ Corticosteroids } & Methylprednisolone & $40 \mathrm{mg} / \mathrm{mL}[160]$ & $0.4-4 \mathrm{mg} / \mathrm{mL}[160]$ & $1 \%$ pet; $1 \%$ alc $[157]$ \\
\hline & & $2-20 \mathrm{mg} / \mathrm{mL}[161]$ & $0.2-2 \mathrm{mg} / \mathrm{mL}[161]$ & \\
\hline & Hydrocortisone & $100 \mathrm{mg} / \mathrm{mL}[29]$ & $10 \mathrm{mg} / \mathrm{mL}[29]$ & $0.5 \%$ alc or DMSO, \\
\hline & Triamcinolone & $4-40 \mathrm{mg} / \mathrm{mL}[29]$ & $0.4-4 \mathrm{mg} / \mathrm{mL}[29]$ & $1 \%$ pet $[157]$ \\
\hline & & & & $1 \%$ alc, $2 \%$ pet $[157]$ \\
\hline & & & & $0.25 \%-1 \%$ pet $[29]$ \\
\hline & Paramethasone & $20 \mathrm{mg} / \mathrm{mL}[29]$ & $0.2-2 \mathrm{mg} / \mathrm{mL}[29]$ & $2 \%$ alc $[157]$ \\
\hline & Budesonide & $0.5 \mathrm{mg} / \mathrm{mL}[29]$ & $0.005 \mathrm{mg} / \mathrm{mL}$ [29] & $0.1 \%$ pet $[157]$ \\
\hline & & & & $0.01-0.1 \%$ pet $[29]$ \\
\hline & Dexamethasone & $4 \mathrm{mg} / \mathrm{mL}[160]$ & $0.04-0.4 \mathrm{mg} / \mathrm{mL}[160]$ & $0.1 \%$ alc $[157]$ \\
\hline & & & & $1 \%-25 \%$ pet $[29]$ \\
\hline & Betamethasone & $4 \mathrm{mg} / \mathrm{mL}[29]$ & $0.4 \mathrm{mg} / \mathrm{mL}[29]$ & $0.1 \%$ alc $[157]$ \\
\hline & & & & $1 \%-5 \%$ pet $[29]$ \\
\hline & Fluticasone & Undiluted [29] & $1 / 100[29]$ & $0.1 \%$ alc $[157]$ \\
\hline \multirow[t]{3}{*}{ Miscellaneous } & Ivermectin & NR & NR & NR \\
\hline & Icatibant & NR & $\mathrm{NR}$ & NR \\
\hline & Heparins & Undiluted [29] & $1 / 100$ to $1 / 10[151]$ & Undiluted $[29,161]$ \\
\hline \multirow[t]{11}{*}{ Excipients } & Cremophor EL & $1 / 1000$ to $1 / 1[73,74]$ & $1 / 1000$ to $1 / 100[73,74]$ & \\
\hline & & & $1-10 \mathrm{mg} / \mathrm{mL}[29]$ & \\
\hline & Carboxymethyl & $5 \mathrm{mg} / \mathrm{mL}[29]$ & $0.05-0.005 \mathrm{mg} / \mathrm{mL}[29]$ & $2 \%$ pet $[157]$ \\
\hline & cellulose $1 \%$ & Undiluted [162] & $1 / 10[108]$ & \\
\hline & Povidone & Undiluted [29] & $1 / 1000[29]$ & $5-10 \%$ aq or pet, \\
\hline & & $35 \mathrm{mg} / \mathrm{mL}[108]$ & & $0.5 \%$ alc $[157]$ \\
\hline & & $100 \mathrm{mg} / \mathrm{mL}[162]$ & & \\
\hline & Macrogol & $50 \%$-Undiluted [162] & $1 / 10000$ to $1 / 100[162] \mathrm{a}$ & $1-5 \%$ pet $[157]$ \\
\hline & $\begin{array}{l}\text { (polyethylene glycol } \\
\text { high molecular weight) }\end{array}$ & & & \\
\hline & Polysorbate 80 & $0.04-0.15 \mathrm{mg} / \mathrm{mL}[29]$ & $1 / 1000$ to $1 / 10 \mathrm{mg} / \mathrm{mL}$ [29] & $5 \%$ aq or pet $[157]$ \\
\hline & & $20 \%[162]$ & & \\
\hline
\end{tabular}

Abbreviations: CQ, chloroquine; DMSO, dimethyl sulfoxide; HCQ, hydroxychloroquine; IDT, intradermal test; NR, not reported.

aHigh risk of systemic reactions 
to provide appropriate and timely data for interdepartmental consultations in this area.

\section{Funding}

The authors declare that no funding was received for the present study.

\section{Conflicts of Interest}

The authors declare that they have no conflicts of interest.

\section{References}

1. Zhu N, Zhang D, Wang W, Li X, Yang B, Song J, et al. China Novel Coronavirus Investigating and Research Team. A novel coronavirus from patients with pneumonia in China. N Engl J Med. 2020;382:727-33.

2. Wu Z, McGoogan JM. Characteristics of and important lessons from the coronavirus disease 2019 (COVID-2019) outbreak in China: summary of a report of 72314 cases from the Chinese Center for Disease Control and Prevention. JAMA. 2020;323:1239-42

3. Sanders JM, Monogue ML, Jodlowski TZ, Cutrell JB. Pharmacologic Treatments for Coronavirus Disease 2019 (COVID-19): A Review. JAMA. 2020;10.1001/ jama.2020.6019.

4. Wang $M$, Cao R, Zhang L, Yang X, Liu J, Xu M, et al. Remdesivir and chloroquine effectively inhibit the recently emerged novel coronavirus (2019-nCov) in vitro. Cell Res. 2020;30:269-71.

5. Cao B, Wang Y, Wen D, et al. A Trial of Lopinavir-Ritonavir in Adults Hospitalized with Severe Covid-19. N Engl J Med. 2020;382:1787-99

6. Russell CD, Millar JE, Baillie JK. Clinical evidence does not support corticosteroid treatment for 2019-nCoV lung injury. Lancet. 2020:395:473-5.

7. Mehta P, McAuley DF, Brown M, Sanchez E, Tattersall RS, Manson JJ. COVID-19: consider cytokine storm syndromes and immunosuppression. Lancet. 2020;395:1033-4.

8. Siddiqi HK, Mehra MR. COVID-19 illness in native and immunosuppressed states: A clinical-therapeutic staging proposal. J Heart Lung Transplant. 2020;39:405-7.

9. Chu CM, Cheng VC, Hung IF, Wong MM, Chan KH, Chan KS, et al. HKU/UCH SARS Study Group. Role of lopinavir/ritonavir in the treatment of SARS: initial virological and clinical findings. Thorax. 2004;59:252-6.

10. Yao TT, Qian JD, Zhu WY, Wang Y, Wang GQ. A systematic review of lopinavir therapy for SARS coronavirus and MERS coronavirus-A possible reference for coronavirus disease-19 treatment option. J Med Virol. 2020;92:556-63.

11. Kang S-Y, Sohn K-H, Lee J-O, Kim S-H, Cho S-H, Chang Y-S. Intravenous tacrolimus and cyclosporine induced anaphylaxis: what is next? Asia Pac Allergy. 2015;5:181-6.

12. Manfredi R, Sabbatani S, Bergonzi S. Clinical Ritonavir and Lopinavir Hypersensitivity Confirmed by a Specific In Vitro Cellular Allergen Stimulation Test. Curr HIV Res. 2007;5:4402.

13. Calista D. Maculo-papular rash induced by lopinavir/ritonavir. Eur J Dermatol. 2005;15:97-8.
14. Ghosn J, Duvivier C, Tubiana R, Katlama C, Caumes E. Acute Generalized Exanthematous Pustulosis Induced by HIV Postexposure Prophylaxis with Lopinavir-Ritonavir. Clin Infect Dis. 2005;41:1360-1.

15. Manfredi R, Sabbatani S. Serious, multi-organ hypersensitivity to lopinavir alone, involving cutaneous-mucous rash, and myeloid, liver, and kidney function. AIDS. 2006;20:2399400.

16. Al-Tawfiq JA, Al-Homoud AH, Memish ZA. Remdesivir as a possible therapeutic option for the COVID-19. Travel Med Infect Dis. 2020;34:101615.

17. Grein J, Ohmagari N, Shin D, Diaz G, Asperges E, Castagna $A$, et al. Compassionate Use of Remdesivir for Patients with Severe Covid-19. N Engl J Med. 2020;382:2327-36.

18. Ohe $M$, Shida $H$, Jodo $S$, et al. Macrolide treatment for COVID-19: Will this be the way forward? Biosci Trends. 2020;14:159-160.

19. Barni S, Butti D, Mori F, Pucci N, Rossi ME, Cianferoni A, et al. Azithromycin is more allergenic than clarithromycin in children with suspected hypersensitivity reaction to macrolides. J Investig Allergol Clin Immunol. 2015;25:128-32.

20. Blumenthal KG, Peter JG, Trubiano JA, Phillips EJ. Antibiotic allergy. Lancet. 2019;393:183-98.

21. Sánchez-Borges M, Thong B, Blanca M, Ensina LFC, GonzálezDíaz S, Greenberger PA, et al. Hypersensitivity reactions to non beta-lactam antimicrobial agents, a statement of the WAO special committee on drug allergy. World Allergy Organ J. 2013;6:18.

22. An I, Demir $V_{1}$ Akdeniz S. Fixed drug eruption probably induced by azithromycin. Australas J Dermatol. 2017;58:e253-4.

23. Sriratanaviriyakul N, Nguyen LP, Henderson MC, Albertson TE. Drug reaction with eosinophilia and systemic symptoms syndrome (DRESS) syndrome associated with azithromycin presenting like septic shock: a case report. J Med Case Rep. 2014:8:332.

24. Campanón-Toro MV, Sierra O, Moreno E, SobrinoGarcía M, Gracia-Bara MT, Dávila I. Acute generalized exanthematouspustulosis (AGEP) induced by azithromycin. Contact Dermatitis. 2017;76:363-4.

25. Aihara $Y$, Ito S, Kobayashi $Y$, Aihara M. Stevens-Johnson syndrome associated with azithromycin followed by transient reactivation of herpes simplex virus infection. Allergy. 2004;59:118.

26. Xu L, Zhu Y, Yu J, Deng M, Zhu X. Nursing care of a boy seriously infected with Steven-Johnson syndrome after treatment with azithromycin: A case report and literature review. Medicine (Baltimore). 2018;97:e9112.

27. Odemis E, Kalyoncu M, Okten A, Yildiz K. Azithromycin-induced leukocytoclastic vasculitis. J Rheumatol. 2003;30:2292.

28. Martínez MA, Vuppalanchi R, Fontana RJ, Stolz A, Kleiner $\mathrm{DE}$, Hayashi PH, et al. Clinical and histological features of azithromycin-induced liver injury. Clin Gastroenterol Hepatol. 2015:13:369-76.

29. Lobera-Labairu T, Padial-Vílchez MA, Guerrero-garcía MA, Audicana-Berasategui MT, García-Abujeta JL. Concentraciones de principios activos y excipientes empleados para la realización de pruebas cutáneas y epicutáneas. In: Dávila I, Jáuregui I, Olaguíbel JM, Zubeldia JM, eds. Tratado de Alergología SEAIC, España: 2ª edición, 2016;1657-95. 
30. García-Robaina JC, Lobera-Labairu T, Padial-Vílchez MA, DoñaDíaz I. Hipersensibilidad a los antibióticos no betalactámicos. In: Dávila I, Jáuregui I, Olaguíbel JM, Zubeldia JM, eds. Tratado de Alergología SEAIC, España: 2a edición, 2016;1515-32.

31. Staso P, Leonov A. Drug desensitization in 17-year-old male with Mast cell Activation Syndrome, pneumonia, and antibiotic hypersensitivities. AME Case Rep. 2017;1:7.

32. Zhou D, Dai SM, Tong Q. COVID-19: a recommendation to examine the effect of hydroxychloroquine in preventing infection and progression. J Antimicrob Chemother. 2020;dkaa114.

33. Devaux CA, Rolain JM, Colson P, Raoult D. New insights on the antiviral effects of chloroquine against coronavirus: what to expect for COVID-19? Int J Antimicrob Agents. 2020;55:105938.

34. Soria A, Barbaud A, Assier $H$, Avenel-Audran M, Tétart $F$, Raison-Peyron $\mathrm{N}$, et al. Cutaneous adverse drug reactions with antimalarials and allergological skin tests. Dermatology. 2015;231:353-9.

35. Matsuda T, Ly NTM, Kambe N, Nguyen CTH, UedaHayakawa I, Son Y, et al. Early cutaneous eruptions after oral hydroxychloroquine in a lupus erythematosus patient: A case report and review of the published work. J Dermatol. 2018;45:344-8.

36. Pérez-Ezquerra PR, de Barrio Fernández M, de Castro Martínez FJ, Ruiz Hornillos FJ, Prieto García A. Delayed hypersensitivity to hydroxychloroquine manifested by two different types of cutaneous eruptions in the same patient. Allergol Immunopathol. 2006;34:174-5.

37. Kanny G, Renaudin JM, Lecompte T, Moneret-Vautrin DA. Chloroquine hypersensitivity syndrome. Eur J Intern Med. 2002:13:75-6.

38. Cameron MC, Word AP, Dominguez A. Hydroxychloroquineinduced fatal toxic epidermal necrolysis complicated by angioinvasive rhizopus. Dermatol Online J. 2014;20:11.

39. Charfi O, KastalliS, Sahnoun R, Lakhoua G. Hydroxychloroquineinduced acute generalized exanthematous pustulosis with positive patch-testing. Indian J Pharmacol. 2015;47:693-4.

40. Donado CD, Díez EM. Successful Desensitization for Hydroxychloroquine Anaphylaxis. J Rheumatol. 2010;37:1975-6.

41. Tal Y, Maoz Segal R, Langevitz P, Kivity S, Darnizki Z, AgmonLevin N. Hydroxychloroquine desensitization, an effective method to overcome hypersensitivity-a multicenter experience. Lupus. 2018;27:703-7.

42. Barailler H, Milpied B, Chauvel A, Claraz P, Taïeb A, Seneschal J, et al. Delayed hypersensitivity skin reaction to hydroxychloroquine: successful short desensitization. J Allergy Clin Immunol Pract. 2019;7:307-8.

43. Mates M, Zevin S, Breuer GS, Navon P, Nesher G. Desensitization to hydroxychloroquine-experience of 4 patients. J Rheumatol. 2006;33:814-6.

44. Rowane M, Schend J, Patel J, Hostoffer R. Rapid desensitization to hydroxychloroquine. Ann Allergy Asthma Immunol. 2020;124:97-8.

45. Channappanavar R, Perlman S. Pathogenic human coronavirus infections: causes and consequences of cytokine storm and immunopathology. Semin Immunopathol. 2017;39:529-39.

46. Xu X, Han M, Li T, Sun W, Wang D, Fu B, et al. Effective treatment of severe COVID-19 patients with tocilizumab. Proc Natl Acad Sci U S A. 2020;117:10970-5.
47. Galvao VR, Castells MC. Hypersensitivity to biological agentsUpdated diagnosis, management and treatment. J Allergy Clin Immunol Pract. 2015;3:175-85.

48. Puxeddu I, Caltran E, Rocchi V, Del Corso I, Tavoni A, Migliorini P. Hypersensitivity reactions during treatment with biological agents. Clin Exp Rheumatol. 2016;3481:129-32.

49. Tétu $P$, Hamelin A, Moguelet $P$, Barbaud A, Soria A Management of hypersensitivity reactions to tocilizumab. Clin Exp Allergy. 2018;48:749-52

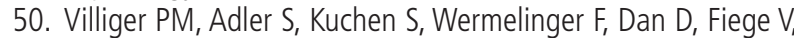
et al. Tocilizumab for induction and maintenance of remission in giant cell arteritis: a phase 2, randomised, double-blind, placebo-controlled trial. Lancet. 2016;387:1921-7.

51. Izquierdo JH, Bonilla-Abadía F, Ochoa CD, Agualimpia A, Tobón GJ, Cañas CA. Acute Generalized Exanthematous Pustulosis due to Tocilizumab in a Rheumatoid Arthritis Patient. Case Rep Rheumatol. 2012;2012:517424.

52. Rocchi V, Puxeddu I, Cataldo G, Del Corso I, Tavoni A, Bazzichi $L$, et al. Hypersensitivity reactions to tocilizumab: role of skin tests in diagnosis. Rheumatology (Oxford). 2014:53:1527-9.

53. Cortellini G, Mascella F, Simoncelli M, Lippolis D, Focherini $M C$, Cortellini $F$, et al. Effective desensitization to tocilizumab in delayed hypersensitivity reaction. Pharmacology. 2018;102:114-6.

54. Cansever M, Sahin N, Dursun I, Geyik C, Düşünsel R, Bektaş Kut $F$, et al. Successful slow desensitization to tocilizumab in a 15-year-old patient. J Investig Allergol Clin Immunol. 2018;28:436-8

55. Erdogan T, Yasar Bilge NS, Kasifoglu T. Successful slow tocilizumab desensitization in a patient with adult onset Still disease. Biologicals. 2018;55:17-8.

56. Demir S, Soyer O, Bilginer Y, Sag E, Umit Murat S, Buyuktiryaki $B$, et al. Desensitisation overcomes rituximab- and tocilizumabrelated immediate hypersensitivity in childhood. Clin Exp Rheumatol. 2020;38:552-7.

57. Wells AF, Parrino J, Mangan EK, Paccaly A, Lin $Y, X u$ C, et al. Immunogenicity of sarilumab monotherapy in patients with rheumatoid arthritis who were inadequate responders or intolerant to disease-modifying antirheumatic drugs. Rheumatol Ther. 2019;6:339-52.

58. Burmester GR, Lin $Y$, Patel $R$, van Adelsberg J, Mangan EK, Graham NMH, et al. Efficacy and safety of sarilumab monotherapy versus adalimumab monotherapy for the treatment of patients with active rheumatoid arthritis (MONARCH): a randomised, double-blind, parallel-group phase III trial. Ann Rheum Dis. 2017;76:840-7.

59. Dinarello CA. Interleukin-1 in the pathogenesis and treatment of inflammatory diseases. Blood. 2011;117:3720-32.

60. Monteagudo LA, Boothby A, Gertner E. Continuous Intravenous Anakinra Infusion to Calm the Cytokine Storm in Macrophage Activation Syndrome. ACR Open Rheumatol. 2020:2:276-82

61. Kaiser C, Knight A, Nordström D, Pettersson T, Fransson J, Florin-Robertsson $\mathrm{E}$, et al. Injection-site reactions upon Kineret (anakinra) administration: experiences and explanations. Rheumatol Int. 2012;32:295-9.

62. Aguiar CL, Pan N,AdamsA, Barinstein L, LehmanTJ.Anaphylaxis to anakinra in a pediatric patient with systemic juvenile 
idiopathic arthritis successfully treated with canakinumab: a case-based review. Clin Rheumatol. 2015;34:1821-4.

63. Desai D, Goldbach-Mansky R, Milner JD, Rabon RL, Hull $\mathrm{K}$, Pucino $\mathrm{F}$, et al. Anaphylactic reaction to anakinra in a rheumatoid arthritis patient intolerant to multiple nonbiologic and biologic disease-modifying antirheumatic drugs. Ann Pharmacother. 2009;43:967-72.

64. Şoyyiğit S, Kendirlinan R, Aydın O, Çelik GE. Successful desensitization with anakinra in a case with immediate hypersensitivity reaction. Ann Allergy Asthma Immunol. 2014;113:325-6.

65. YIlmaz I, Türk M, NazikBahçecioğlu S. Successful rapid subcutaneous desensitization to anakinra in a case with a severe immediate-type hypersensitivity reaction. Eur Ann Allergy Clin Immunol. 2018;50:94-6.

66. Palacios Castano M, Venturini Diaz M, Lobera Labairu T, Gonzalez Mahave I, Del Pozo Gil M, Blasco Sarramian A. Anaphylaxis due to the excipient polysorbate 80. J Investig Allergol Clin Immunol. 2016;26:394-6.

67. Badiu I, Geuna M, Heffler E, Rolla G. Hypersensitivity reaction to human papillomavirus vaccine due to polysorbate 80 . BMJ Case Rep. 2012;2012:bcr0220125797.

68. Coors EA, Seybold H, Merk HF, Mahler V. Polysorbate 80 in medical product and non-immunologic anaphylactoid reactions. Ann Allergy Asthma Immunol. 2005;95:593-9.

69. Richardson P, Griffin I, Tucker C. Baricitinib as potential treatment for 2019-nCoV acute respiratory disease. Lancet. 2020;395:e30-1.

70. Koumaki D, Koumaki V, Lagoudaki E, Bertsias G. Palmoplantar Pustulosis-like Eruption Induced by Baricitinib for Treatment of Rheumatoid Arthritis. Eur J Case Rep Intern Med. 2019;7:001383.

71. De Wilde $A H$, Zevenhoven-Dobbe JC, van der Meer $Y$, Thiel $V$, Narayanan K, Makino S, et al. Cyclosporin A inhibits the replication of diverse coronaviruses. J Gen Virol. 2011;92:2542-8.

72. Tanaka Y, Sato Y, Sasaki T. Suppression of coronavirus replication by cyclophilin inhibitors. Viruses. 2013;5:1250-60.

73. Ebo DG, Piel GC, Conraads V, Stevens WJ. IgE-mediated anaphylaxis after the first intravenous infusion of cyclosporine. Ann Allergy Asthma Immunol. 2001;87:243-5.

74. Cooney GF, Alpern JB, Narins BE, Goetz LK, Cavarocchi NC. Tolerance of cyclosporine oral capsules in a patient hypersensitive to standard oral and intravenous solutions of the drug. Transplantation. 1990;49:823-4.

75. Volcheck GW, Van Dellen RG. Anaphylaxis to intravenous cyclosporine and tolerance to oral cyclosporine: case report and review. Ann Allergy Asthma Immunol. 1998;80:159-63.

76. Moeinian M, Sotoude $H$, Mohebbi Z, Asadollahi-Amin A, Mozafari R. Well-tolerated oral cyclosporine in a case of hypersensitivity to parenteral cyclosporine in postallogeneic bone marrow transplantation. Indian J Pharmacol. 2018;50:94-6

77. Takamatsu $Y$, Ishizu $M$, Ichinose I, Ogata $K$, Onoue $M$, Kumagawa $\mathrm{M}$, et al. Intravenous cyclosporine and tacrolimus caused anaphylaxis but oral cyclosporine capsules were tolerated in an allogeneic bone marrow transplant recipient. Bone Marrow Transplant. 2001;28:421-3.
78. Sumptom JE, White CT, Rieder MJ, D'Souza SJ. Hypersensitivity to cyclosporine (Neoral) and successful desensitization. Transplant Proc. 2001;33:3015-7.

79. Hirano K, Ichikawa T, Nakao K, Matsumoto A, Miyaaki $H$, Shibata $H$, et al. Differential effects of calcineurin inhibitors, tacrolimus and cyclosporin, on interferon-induced antiviral protein in human hepatocyte cells. Liver Transpl. 2008; 1483:202-8.

80. Nicolai S, Bunyavanich S. Hypersensitivity reactions to intravenous but not oral tacrolimus. Transplantation. 2012;94:e61-3.

81. Shaw DW, Eichenfield LF, Shainhouse T, Maibach HI. Allergic contact dermatitis from tacrolimus. J Am Acad Dermatol. 2004;50:962-5.

82. Darlenski R. Probable contact urticaria caused by tacrolimuscontaining ointment in the treatment of atopic dermatitis. J Allergy Clin Immunol Pract. 2019;7:1665-7.

83. Scherrer M, Araujo MG, Farah K. Tacrolimus-induced symmetric drug-related intertriginous and flexural exanthema (SDRIFE). Contact Dermatitis. 2018;78:414-6.

84. Riley L, Mudd L, Baize T, Herzig R. Cross-sensitivity reaction between tacrolimus and macrolide antibiotics. Bone Marrow Transplant. 2000;25:907-8.

85. Trofe-Clark J, Doshi M, Fadugba O, Lim MA. Evaluation of allergy to tacrolimus in kidney transplant candidates and recipients with a history of macrolide antibiotic allergy. Am J Transplant. 2018;18:1831-2.

86. DevonshireAL, BalmertLC, Kumar R.Pediatric posttransplantation food allergy experience at a large US tertiary care center. Ann Allergy Asthma Immunol. 2019;123:522-4.

87. Caly L, Druce JD, Catton MG, Jans DA, Wagstaff KM. The FDAapproved drug ivermectin inhibits the replication of SARSCoV-2 in vitro. Antiviral Res. 2020;178:104787.

88. Chaccour C, Hammann F, Ramón-García S, Rabinovich NR. Ivermectin and COVID-19: Keeping Rigor in Times of Urgency. Am J Trop Med Hyg. 2020;102:1156-7.

89. Marty P, Gari-Toussaint M, LeFichoux Y, Gaxotte P. Efficacy of ivermectin in the treatment of an epidemic of sarcoptic scabies. Ann Trop Med Parasitol. 1994;88(4):453.

90. Usha V, Gopalakrishnan Nair TV. A comparative study of oral ivermectin and topical permethrin cream in the treatment of scabies. J Am Acad Dermatol. 2000;42:236-40.

91. Dourmishev AL, Serafimova DK, Dourmishev LA. Efficacy and tolerance of oral ivermectin in scabies. J Eur Acad Dermatol Venereol. 1998;11:247-51.

92. Seegobin K, Bueno E, Maharaj S, Ashby T, Brown M, Jones L. Toxic epidermal necrolysis after ivermectin. Am J Emerg Med. 2018;36:887-9.

93. Aroke D, Tchouakam DN, Awungia AT, Mapoh SY, Ngassa SN, Kadia BM. Ivermectin induced Steven-Johnson syndrome: case report. BMC Res Notes. 2017.10:179.

94. Kerneuzet I, Blind E, Darrieux L, Moreau S, Safa G. Ivermectininduced drug reaction with eosinophilia and systemic symptoms (DRESS) syndrome. JAAD Case Rep. 2018;4:524-7.

95. Ngwasiri CA, Abanda MH, Aminde LN. Ivermectin-induced fixed drug eruption in an elderly Cameroonian: a case report. J Med Case Rep. 2018;12:254.

96. Tolouian R, ZununiVahed S, Ghiyasvand S, Tolouian A, Ardalan M. COVID-19 interactions with angiotensin-converting 
enzyme 2 (ACE2) and the kinin system; looking at a potential treatment. J Ren Inj Prev. 2020;9:19.

97. Sodhi CP, Wohlford-Lenane C, Yamaguchi Y, Prindle T, Fulton WB, Wang $S$, et al. Attenuation of pulmonary ACE2 activity impairs inactivation of des-Arg 9 bradykinin/BKB1R axis and facilitates LPS induced neutrophil infiltration. Am J Physiol Lung Cell Mol Physiol 2018:314;17-31.

98. Roche JA, Roche R. A hypothesized role for dysregulated bradykinin signaling in COVID-19 respiratory complications. FASEB J. 2020;34:7265-9.

99. van de Veerdonk FL, Netea MG, van Deuren M, et al. Kallikreinkinin blockade in patients with COVID-19 to prevent acute respiratory distress syndrome. Elife. 2020;9:e57555.

100. Liu X, Wang XJ. Potential inhibitors against 2019-nCoV coronavirus $\mathrm{M}$ protease from clinically approved medicines. $J$ Genet Genomics. 2020;47:119-21.

101. Jeon J, Lee YJ, Lee S. Effect of icatibant on angiotensinconverting enzyme inhibitor-induced angioedema: a metaanalysis of randomized controlled trials. J Clin Pharm Ther 2019;44:685-92.

102. Farkas $H$, Reshef $A$, Aberer W, Caballero T, McCarthy L, Hao $J$, et al. Treatment effect and safety of icatibant in pediatric patients with hereditary angioedema. J Allergy Clin Immunol Pract. 2017:5:1671-8.e2

103. Deeks ED. Icatibant. Drugs. 2010;70:73-81.

104. Gras J. Icatibant for hereditary angioedema. Drugs Today (Barc). 2009:45:855-64.

105. Stockman LJ, Bellamy R, Garner P. SARS: systematic review if treatment effects. PLoS Med. 2006;3:e343.

106. Arabi YM, Mandourah Y, Al-Hameed F, Sindi AA, Almekhlafi GA, Hussein MA, et al. Corticosteroid therapy for critically ill patients with Middle East Respiratory Syndrome. Am J Respir Crit Care Med. 2018;197:757-67.

107. https://www.recoverytrial.net/news/low-costdexamethasone-reduces-death-by-up-to-one-third-inhospitalised-patients-with-severe-respiratory-complicationsof-covid-19

108. Rosado-Ingelmo A, García-Robaina JC, García-Avilés C, Vila-Albelda C. Reacciones de hipersensibilidad a fármacos poco habituales. In: Dávila I, Jáuregui I, Olaguíbel JM, Zubeldia JM, eds. Tratado de Alergología SEAIC, España: 2a edición:1612-44.

109. Torres MJ, Canto G. Hypersensitivity reactions to corticosteroids. Curr Opin Allergy Clin Immunol. 2010;10:273-9.

110. Vatti RR, Ali F, Teuber S, Chang C, Gershwin ME. Hypersensitivity reactions to corticosteroids. Clin Rev Allergy Immunol. 2014:47:26-37.

111. Li PH, Wagner A, Thomas I, Watts TJ, Rutkowski R, Rutkowski K. Steroid allergy: clinical features and the importance of excipient testing in a diagnostic algorithm. J Allergy Clin Immunol Pract. 2018;6:1655-61.

112. Kamm GL, Hagmeyer KO. Allergic-type reactions to corticosteroids. Ann Pharmacother. 1999:33:451-60.

113. Coopman S, Degreef $H$, Dooms-Goosens A. Identification of cross-reactions patterns in allergic contact dermatitis from topical corticosteroids. Br J Dermatol. 1989;121:27-34.

114. Barbaud A, Waton J. Systemic allergy to corticosteroids: clinical features and cross-reactivity. Curr Pharm Des. 2016:22:682531.
115. Isaksson M. Corticosteroid contact allergy - the importance of late readings and testing with corticosteroids used by the patient. Contact Dermatitis. 2007;56:56-7.

116. Hannuksela M, Salo $H$. The repeated open application test (ROAT). Contact Dermatitis. 1986;14:221-7.

117. Patel A, Bahna SL. Immediate hypersensitivity reactions to corticosteroids. Ann. Allergy Asthma Immunol. 2015;115;178-82.

118. Aranda A, Mayorga C, Ariza A, et al. IgE-mediated hypersensitivity reactions to methylprednisolone. Allergy. 2010;65:1376-80

119. Baeck M, Chemelle JA, Goosens A, Nicolas JF, Terreux R. Corticosteroid cross-reactivity: clinical and molecular modelling tools. Allergy. 2011;66:1367-74.

120. Rodrigues-Alves R, Spínola-Santos A, Pedro E, BrancoFerreira M, Pereira-Barbosa M. Immediate hypersensitivity to corticosteroids: finding an alternative. J Investig Allergol Clin Immunol. 2007;17:284-5

121. Lee-Wong $M, M c C l e l l a n d ~ S$, Chong $K$, Fernández-Pérez ER. A case of hydrocortisone desensitization in a patient with radio contrast-induced anaphylactoid reaction and corticosteroid allergy. Allergy Asthma Proc. 2006;27:265-8.

122. Angel-Pereira D, Berges-Gimeno MP, Madrigal-Burgaleta $R$, Ureña-Tavera MA, Zamora-Verduga M, Álvarez-Cuesta E. Successful rapid desensitization to methylprednisolone sodium hemisuccinate: A case report. J Allergy Clin Immunol Pract. 2014:2:346-8.

123. Alban S. From heparins to factor $X a$ inhibitors and beyond. Eur J Clin Invest. 2005;35:12-20.

124. Rodríguez-Fernández $A$, Sánchez-Domínguez M, TorradoEspañol I, Noguerado-Mellado B, Rojas-Pérez-Ezquerra P. Clinical Patterns of Heparin Allergy: Cross-reactivity Between Low-Molecular-Weight Heparins and Unfractionated Heparins. J Investig Allergol Clin Immunol. 2019;29:132-4.

125. Chen N, Zhou M, Dong $X, Q u$ J, Gong $F$, Han $Y$, et al. Epidemiological and clinical characteristics of 99 cases of 2019 novel coronavirus pneumonia in Wuhan, China: a descriptive study. Lancet. 2020;395:507-13.

126. Huang C, Wang Y, Li X, Ren L, Zhao J, Hu Y, et al. Clinical features of patients infected with 2019 novel coronavirus in Wuhan, China. Lancet. 2020;15;395:497-506.

127. Tang N, Li D, Wang X, Sun Z. Abnormal coagulation parameters are associated with poor prognosis in patients with novel coronavirus pneumonia. J Thromb Haemost. 2020;18:844-7.

128. Bikdeli B, Madhavan MV, Jimenez D, Chuich T, Dreyfus I, Driggin E, et al. COVID-19 and Thrombotic or Thromboembolic Disease: Implications for Prevention, Antithrombotic Therapy, and Follow-Up: JACC State-of-the-Art Review. J Am Coll Cardiol. 2020;75:2950-73.

129. Trautmann A, Hamm K, Bröcker EB, et al. Delayed hypersensitivity to heparins. Clinical signs, diagnosis, therapeutic alternatives. Z Hautkr. 1997;72:447-50.

130. Bircher AJ, Flückiger R, Buchner SA. Eczematous infiltrated plaques to subcutaneous heparin: a type IV allergic reaction. Br J Dermatol. 1990;123:507-14.

131. Klein GF, Kofler H, WolfH, Fritsch PO. Eczema-like, erythematous, infiltrated plaques: a common side effect of subcutaneous heparin therapy. J Am Acad Dermatol. 1989;21:703-7.

132. Pföhler C, Müller C, Pindur G, Eichler G, Schäfers HJ, Grundmann U, et al. Delayed-Type Heparin Allergy: Diagnostic 
Procedures and Treatment Alternatives.VA Case Series Including 15 Patients. WAO Journal. 2008;1:194-9.

133. Trautmann A, Seitz CS. Heparin allergy: delayed-type non-lgEmediated allergic hypersensitivity to subcutaneous heparin injection. Immunol Allergy Clin North Am. 2009;29:469-80.

134. Seitz CS, Bröcker EB, Trautmann A. Management of allergy to heparins in postoperative care: subcutaneous allergy and intravenous tolerance. Dermatol Online J. 2008;14:4

135. Grims RH, Weger W, Reiter H, Arbab E, Kränke B, Aberer W. Delayed-type hypersensitivity to low molecular weight heparins and heparinoids: cross-reactivity does not depend on molecular weight. Br J Dermatol. 2007;157:514-7.

136. Jappe U, Reinhold D, Bonnekoh B. Arthus reaction to lepirudin, a new recombinant hirudin, and delayed-type hypersensitivity to several heparins and heparinoids, with tolerance to its intravenous administration. Contact Dermatitis. 2002;46:29-32.

137. Ronceray S, Dinulescu M, Le Gall F, Polard E, Dupuy A, Adamski H. Enoxaparin-induced DRESS Syndrome. Case Rep Dermatol. 2012;4:233-7.

138. Bidaki R, Saeidi SA, Zarch MB. Delirious State and Agitation Following Heparin Induced Stevens-Johnson Syndrome. J Clin Diagn Res. 2017;11:VL01.

139. Harenberg J, Hoffmann U, Huhle G, et al. Cutaneous reactions to anticoagulants. Recognition and management. Am J Clin Dermatol. 2001;2:69-75.

140. Harr T, Scherer K, Tsakiris DA, et al. Immediate type hypersensitivity to low molecular weight heparins and tolerance of unfractioned heparin and fondaparinux. Allergy. 2006;61:787-8.

141. Rajka G, Skog E. On the question of heparin hypersensitivity. Acta Derm Venereol.1962;42:27-34.

142. Cesana P, Scherer K, Bircher AJ. Immediate Type Hypersensitivity to Heparins: Two Case Reports and a Review of the Literature. Int Arch Allergy Immunol. 2016;171:285-9.

143. Altintaş ND, Aybar Türkoğlu M, Bozkurt B, Topeli Iskit A, Karakaya G, Kalyoncu AF. Successful heparin desensitization after anaphylactic shock due to heparin. Tuberk Toraks. 2009;57:68-72.

144. al-Eryani AY, al-Momen AK, Fayed DF, Allam AK. Successful heparin desensitization after heparin-induced anaphylactic shock. Thromb Res. 1995;79:523-6.

145. Weberschock T, Meister AC, Bohrt K, Schmitt J, Boehncke WH, Ludwig RJ. The risk for cross-reactions after a cutaneous delayed type hypersensitivity reaction to heparin preparations is independent of their molecular weight: a systematic review. Contact Dermatitis. 2011;65:187-94.

146. Schindewolf $M$, Scheuermann J, Kroll $H$, Garbaraviciene J, Hecking C, Marzi I, et al. Low allergenic potential with fondaparinux: results of a prospective investigation. Mayo Clin Proc. 2010;85:913-9.

147. Maroto-litani M, Higaki Y, Kawashima M. Cutaneous allergic reaction to heparins: subcutaneous but not intravenous provocation. Contact Dermatitis. 2005;52:228-30.

148. Gaigl Z, Pfeuffer P, Raith R, Brocker EB, Traumann A. Tolerance to intravenous heparin in patients with delayed type hypersensitivity to heparins: a prospective study. $\mathrm{Br}$ J Haematol. 2005;128:389-92.

149. González P, de la Sen ML, Ramon A, Soriano V, Cueva B, Fernández J. Immediate hypersensitivity to heparins: a cross- reactivity study. J Investig Allergol Clin Immunol. 2014:24;35270.

150. Caballero MR, Fernandez-Benitez M. Allergy to heparin: A new in vitro diagnostic technique. Allergol et Immunopathol. 2003;31:324-8.

151. Bircher AJ, Harr T, Hohenstein L, Tsakiris DA. Hypersensitivity reactions to anticoagulant drugs: diagnosis and management options. Allergy. 2006;61:1432-40.

152. Strub MB, Brigino-Buenaventura E, Bocobo FR, German DF, Richter RC, Ghotbi $M$, et al. Heparin desensitization in a patient requiring cardiopulmonary bypass for aortic valve replacement (AVR). J Allergy Clin Immunol. 2003. Abstract 877.

153. Dave S, Park MA. Successful heparin desensitization: a case report and review of the literature. J Card Surg. 2008;23:394-7.

154. Parekh K, Burkhart HM, Hatab A, Ross A, Muller BA. Heparin allergy: successful desensitization for cardiopulmonary bypass. J Thorac Cardiovasc Surg. 2005;130:455-1456.

155. Pedrós C, Quintana B, Rebolledo M, Porta N, Vallano A, Arnau $J M$. Prevalence, risk factors and main features of adverse drug reactions leading to hospital admission. Eur J Clin Pharmacol. 2014; $70: 361-7$.

156. Empedrad R, Darter AL, Earl HS, Gruchalla RS. Non irritating intradermal skin test concentrations for commonly prescribed antibiotics. J Allergy Clin Immunol. 2003;112:629-30.

157. De Groot AC. Patch testing. Test concentrations and vehicles for 4350 chemicals. 3rd ed. Elsevier Science; 2008.

158. Milkovic-Kraus S, Macan J, Kanceljak-Macan B. Occupational allergic contact dermatitis from azithromycin in pharmaceutical workers: a case series. Contact Dermatitis. 2007;56:99-102.

159. Corominas M, Gastaminza G, Lobera T. Hypersensitivity reactions to biological drugs. J Investig Allergol Clin Immunol. 2014;24:212-25.

160. Venturini M, Lobera T, Del Pozo MD, González I, Blasco A. Immediate hypersensitivity to corticosteroids. J Investig Allergol Clin Immunol. 2006;16:51-6.

161. Brockow K, Garvey LH, Aberer W, Atanaskovic-Markovic M, Barbaud A, Bilo MB, et al; ENDA/EAACI Drug Allergy Interest group. Skin test concentrations for systemically administered drugs - an ENDA/EAACI Drug Allergy Interest Group position paper. Allergy. 2013;68:702-12.

162. Garvey LH, Ebo DG, Mertes PM, Dewachter P, Garcez T, Kopac $P$, et al. An EAACl position paper on the investigation of perioperative immediate hypersensitivity reactions. Allergy. 2019;74:18712-84.

- Manuscript received May 10, 2020; accepted for publication July 23, 2020.

\section{Valeria Herrera-Lasso Regás}

Unitat d'Al.lergologia, Servei Medicina Interna Hospital Universitari de Bellvitge

Carrer de la Feixa Llarga, s/n

08907 L'Hospitalet de Llobregat, Barcelona, Spain

E-mail: vherreralasso@gmail.com 